\title{
Kernos
}

Revue internationale et pluridisciplinaire de religion grecque antique

$31 \mid 2018$

Varia

\section{The Lost Priestesses of Rhodes? Female Religious Offices and Social Standing in Hellenistic Rhodes}

Juliane Zachhuber

\section{(2) OpenEdition}

\section{Journals}

Electronic version

URL: http://journals.openedition.org/kernos/2686

DOI: 10.4000/kernos.2686

ISSN: 2034-7871

\section{Publisher}

Centre international d'étude de la religion grecque antique

\section{Printed version}

Date of publication: 1 December 2018

Number of pages: 83-110

ISBN: 978-2-87562-055-2

ISSN: 0776-3824

Electronic reference

Juliane Zachhuber, "The Lost Priestesses of Rhodes? Female Religious Offices and Social Standing in Hellenistic Rhodes", Kernos [Online], 31 | 2018, Online since 01 October 2020, connection on 25 January 2021. URL: http://journals.openedition.org/kernos/2686 ; DOI: https://doi.org/10.4000/ kernos. 2686

This text was automatically generated on 25 January 2021.

Kernos 


\title{
The Lost Priestesses of Rhodes? Female Religious Offices and Social Standing in Hellenistic Rhodes
}

\author{
Juliane Zachhuber
}

\begin{abstract}
I am greatly indebted to Robert Parker and Riet van Bremen, who read early drafts of this paper with great care and thoroughness, and gave me invaluable advice for improving it. My deepest thanks also go to Vinciane Pirenne-Delforge, for her helpful comments and kind assistance throughout, and to the two anonymous reviewers whose suggestions and insights were incisive and highly useful to the editing process. Finally, I also wish to extend my gratitude to Philippa Adrych, Elizabeth Foley, and Andy Stiles, who assisted me at various stages of this article's creation. Any mistakes that remain are, of course, my own.
\end{abstract}

\section{Introduction}

1 In his brief discussion of Greek priests and priestesses in the 2004 edited volume on Religions of the Ancient World, Simon Price remarked that "one of the most surprising characteristics of Greek religious personnel is that they consisted equally of men and women". ${ }^{1}$ Given the male-dominated nature of most aspects of Greek life, the existence of priestesses, some of them connected to prominent civic cults, has been seized on by numerous scholars to argue that the religious sphere was the one exception to women's exclusion from public life, "the one arena in which Greek women assumed roles equal and comparable to those of men." Ancient authors seem to confirm this "equality", as when Plato mentions priests and priestesses in one breath in the relevant passage of his Laws, ${ }^{3}$ or as suggested by the numerous cases of female priests found in ancient Greek literature - from Theano in the Iliad to Iphigenia in classical Athenian tragedy.

Since the general rule is usually observed to be that male priests ministered to gods, female priests to goddesses, ${ }^{4}$ it would indeed follow that, given the abundance of female deities, priestesses must surely be equally ubiquitous. Outside our literary sources, we find evidence for historical priestesses in honorific or sacrificial inscriptions, as well as 
in epitaphs and visual imagery. It is largely this body of evidence that forms the basis for such works as Joan Connelly's Portrait of a Priestess, and underlies much of Matthew Dillon's Girls and Women in Classical Greek Religion and Barbara Goff's Citizen Bacchae, ${ }^{5}$ which together have contributed to investigating manifold aspects of women's religion, from different perspectives. In addition, all these works have in common a broad chronological and geographical spread; a wide-angle lens through which to study the still comparatively fragmentary picture of women in Greek religion. Although this approach is laudable, in particular in so far as it removes historians from the traditional Athenocentric bias, it risks painting the general picture at the expense of the idiosyncrasies of individual poleis and their particular contexts, which may in turn throw up significant exceptions or inconsistencies. ${ }^{6}$

3 One such potential danger regards discussions of the supposed ubiquity of priestesses in the Greek world, as well as the common assumption of the "gender rule". It is worth noting that the latter is truly an "assumption", in that it is rarely questioned, or even defined, beyond the vague focus on matching gender - ignoring, for the most part, problems of how "female" goddesses really were. ${ }^{7}$ Many of the suggested explanations of this gender-match are based on plausible but largely conjectural aspects - such as fertility ${ }^{8}$ - which cannot explain why goddesses such as Athena would require female instead of male priests at Athens. Moreover, although this gender pattern does appear to be the norm, it is by no means universal. In addition to cult personnel of Dionysos, which famously subverts this norm, male priests are attested for Athena in Gonnoi, Herakleia under Latmos, Kos, Thera and Tegea, amongst other places, and various examples are cited for other goddesses too in the appendix of Holderman's outdated but still valuable Study of the Greek Priestess. ${ }^{9}$ This observation on its own already suggests that it is time to re-evaluate the evidence for female cult personnel, and the role played by gender requirements.

4 My paper is a contribution to these topics. It questions the prevalence of priestesshoods by examining one local case study from the Hellenistic period: the island-state of Rhodes, located in the south-eastern Aegean. This island recommends itself for interrogation of this topic for two reasons: first, it provides us with a substantial body of (largely epigraphic) evidence for priesthoods, with the names of over 1,500 priests and other religious personnel surviving for the Hellenistic period; and second, despite the existence of this fairly extensive corpus, there is almost no evidence for female priests.

In an attempt to make sense of this deviation from what appears to be the rule, I will pursue three main strands and lines of questioning: first, I will briefly lay out what we know about Rhodian religious personnel and carefully assess the sparse evidence for priestesses against this background. Next, I will consider some possible explanations for this (apparently) exceptional case, such as cultic and regional aspects, or an epigraphic culture that might reflect the particular Rhodian organisation and representation of what we call priesthoods. Finally, I will return to the implications for Rhodian society and for women's access to the public sphere, and ask to what extent this case study alters our perception of the importance of the religious sphere to women's status in Greek society. 


\section{Priests and Priestesses on Rhodes: the Evidence}

6 The state of Rhodes,$^{10}$ as it existed in the Hellenistic period, was the product of a synoikism in the late fifth century between the previously independent poleis of Ialysos, Kameiros, and Lindos. Although unified both politically and geographically in the newly founded city of Rhodes-town at the island's northernmost tip, the three old centres continued to exist for centuries. Rhodians continued to live in them and, more importantly for this paper, they continued to worship the gods of the local pantheons. In terms of cultic organisation too, these subordinate poleis retained a certain amount of autonomy. ${ }^{11}$

7 As mentioned above, the Hellenistic state of Rhodes provides us with a substantial corpus of epigraphic evidence about its religious personnel: their names appear as eponyms in official documents, both of the central polis and of the three constituent communities, in long lists spanning centuries, and in numerous joint dedications and honorific inscriptions. The vast majority of this "priestly epigraphy" falls into three clear categories of documents. The first of these consists of the inscribed catalogues of annual officials, some covering, albeit with occasional gaps, several centuries. Without exception, these list men, most of whom are called "priests" (hiereis) of a mixture of gods and goddesses. Significantly, they include lists of the eponymous hiereis of Lindos and of the Rhodian polis, that is, priests of Athena Lindia and priests of Helios. ${ }^{12}$ These officials certainly had religious titles, but their eponymous role and its political connotations are emphasised overwhelmingly in our sources, while we know very little of their ritual tasks. A catalogue also survives for the eponyms of Kameiros, the socalled damiourgoi - although the nomenclature indicates a different status from the officials of Lindos and Rhodes, there is evidence for priest-like responsibilities, including sacrifice and a connection to the cult of Hestia and Zeus Teleios. ${ }^{13}$ The existence of separate eponyms for Lindos and Kameiros (and probably also Ialysos), demonstrates the significance of marking out the different levels of the Rhodian state through these officials and attests to the political dimension of these "priesthoods" in Rhodes. The second category of inscriptions comprises joint, annual dedications. This provides the most important counterpart to the diachronic evidence of the catalogues. For it seems to have been customary in Kameiros and Lindos for (some) annual religious personnel - or synhiereis ${ }^{14}$ - to inscribe their offices and names at the end of their year in office - always headed by the eponymous priest or damiourgos. Although there are some key differences between the texts from Kameiros and those from Lindos, the basic content, style, and function are similar enough to attribute to a common trait of a Hellenistic Rhodian epigraphic habit. ${ }^{15}$ Again, these texts (numbering over sixty in total, and spanning from the early third century to late first century BC) list only men. The third category consists of honorific monuments, broadly speaking: texts usually inscribed on statue bases commemorating men who served as priests, many however listing no actual honours, either public or private.

8 The particular nature and types of these epigraphic categories will be discussed more fully below as one potential factor explaining the lack of female priests in our records, but it should be noted here that none of these three main types of inscriptions that mention or commemorate priests consists of ritual texts, or texts that we might call "sacred" or "religious". A small number of sacrificial regulations do exist, which mention a variety of religious officials, but they are all short, difficult to date, and 
extremely undetailed. More will be said on this genre, but for now it is worth underlining again the highly civic and even political nature of these priesthoods, as emphasised by the majority of epigraphic document types which record Rhodian religious personnel. A further aspect that emerges from this brief overview of the evidence is the emphasis on the tribal division of the Rhodian state, and the prominence of the sub-polis levels centred on the old cities of Kameiros and Lindos.

It is essential to highlight that the Rhodian evidence, such as it is, presents annually changing male priests of major Rhodian cults of female deities, including Athena Polias, Athena Lindia, Artemis Kekoia and Aphrodite. ${ }^{16}$ This is immediately noteworthy, as it evidently contradicts, or at least offers several exceptions to, the supposed norm of male priests attending to gods, female priests to goddesses. Even more striking, however, is the more general absence of priestesses, not merely from the cults of goddesses, but from almost all Rhodian records - in stark contrast to the prominence of male priests. How can we explain this predominance of men in the cultic organisation of Rhodes?

The epigraphic focus on the priestly eponyms of the different cities, as well as on the other annually rotating priesthoods, reveals a highly-structured system of religious offices. As mentioned above, although most of these magistracies bear religious titles, the surviving evidence stresses their civic importance. Scholars have commented at length on the tribal division that underlay the appointment of the eponymous officials on Rhodes after the synoikism, ${ }^{17}$ and this close link with political identity may be one reason why men were preferred for these priesthoods. The annual nature of most known priesthoods might well be another, related factor. It presumes a high number of eligible candidates, who were able to hold an office for a limited amount of time, often accumulating several of such priesthoods throughout their career. ${ }^{18}$ This distinctively structured system of priesthoods is often assumed to be a product of the synoikism that took place in the late fifth century, an event which certainly had a great impact on the organisation of the citizen body; unfortunately our evidence for the period prior to this unification is so scarce that we cannot tell whether the introduction of these male priesthoods in itself constituted one of the innovations of this process.

Before we turn to the discussion of why cults of female gods were served by men, it is important to note that the absence of women in Rhodian priesthoods, although marked, is not absolute. Even though no priestesses appear in any of the priest lists or joint priestly dedications - the bulk of our evidence for Rhodian priesthoods - there are a small number of dispersed references that prove that at least some female priesthoods did exist in the island state in the Hellenistic period. This sparse testimony consists of two short sacrificial regulations and two or perhaps three honorific documents. The first of the sacrificial texts comes from Ialysos, one of the three original poleis on the island, and, based on its letter forms, is dated to approximately $200 \mathrm{BC}$ :

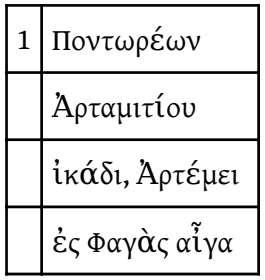


The document specifies one sacrifice to be carried out to Artemis "in Phagai" on the $20^{\text {th }}$ of the month of Artamitios by a priestess in the Ialysian deme Pontoreis. In size and style, the text resembles a number of other cultic inscriptions from Hellenistic Rhodes, which give short, relatively undetailed indications of sacrifices offered to a particular deity on one or several days of the year. Their unusual nature has been commented on by various scholars, and there is disagreement as to their precise function and classification..$^{20}$ The fact that the texts only record offerings to one particular deity, as well as the scattered find-spots, suggest that the documents were affixed to the relevant temple, rather than forming parts of a single sacrificial calendar. They may have functioned as aides-memoire for the sanctuary's officials, or recorded changes to specific sacrifices. As in the cited example, most of these documents name the officiant for the various offerings: we find (male) priests, hieropoioi, the Kameiran damiourgos, hierothytai and an archierothytes. ${ }^{21}$ Aside from the Ialysos example, one further document from this group refers to a priestess, this one from third-century Kameiros:

\begin{tabular}{|c|c|}
\hline \multirow[t]{2}{*}{1} & 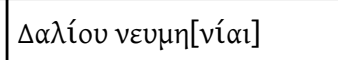 \\
\hline & 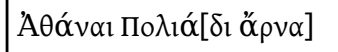 \\
\hline & 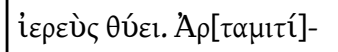 \\
\hline & 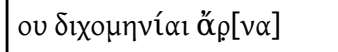 \\
\hline 5 & ióp \\
\hline & 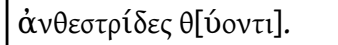 \\
\hline & 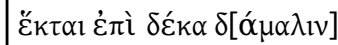 \\
\hline & 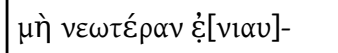 \\
\hline & 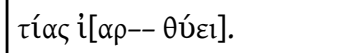 \\
\hline 10 & {$[\text { 'Yo }]_{\kappa i v} \theta[$ íou-- ].22 } \\
\hline
\end{tabular}

As in the previous example, we find succinct regulations for sacrifices to a deity - in this case to Athena Polias, an important goddess in the Kameiran local pantheon. The text has been rather heavily restored, but in its current state ${ }^{23}$ informs us about sacrifices to the goddess at various dates throughout the year by a series of officiants: a priest, who sacrifices an animal on the first of Dalios; a priestess, who sacrifices a sheep at the full-moon in the month of Artamitios; ${ }^{24}$ the anthestrides ("flower girls") who also sacrifice a sheep, presumably on the same occasion; and finally, a fragmentary instruction for a priest (or priestess) to sacrifice what is probably a young heifer on the $16^{\text {th }}$ of the same month. After this, the text breaks off, although it presumably continued to list further offerings to the goddess, sacrificed in other months. Within the context of Rhodian cultic epigraphy, this text is particularly revealing. Male priests of Athena Polias at Kameiros are known in great numbers and various contexts from this very same period: around a hundred survive in a catalogue of priests, while 
dozens of others are attested in joint dedications with other religious officials or in honorific monuments. ${ }^{25}$ But nowhere, in this substantial corpus of documents, do we find mention of a priestess of Athena - except for this fragmentary text. Unlike the local cult of Artemis es Phagas referred to in the first document, this is no obscure or otherwise unknown deity; and yet the existence of a priestess who, as far as we can tell, performed similar duties to the male priest, is only manifest in one document, out of hundreds.

It is telling that, unlike the types of documents described above, these texts refer directly to ritual praxis. Although they only appear twice, female religious officials are on equal footing to their male counterparts in these examples. What is more, the sample of sacrificial texts from Rhodes is so limited anyway, that two instances are arguably not as negligible or unrepresentative as one might think. This applies even more to the inscription relating to the Artemis cult of the Pontoreis - evidence for cultic organisation at deme-level is extremely sparse in Hellenistic Rhodes, making the role and responsibility of this priestess all the more significant.

The remaining attestations of Rhodian priestesses appear in honorific documents, which, we may remember, formed one of the three main categories of "priestly epigraphy" discussed above. All are later in date than the previous texts. Two refer to priestesses of the same goddess, Artemis Pergaia, although since the texts come from different cities, it is possible that they in fact refer to two separate cults.

The first inscription was discovered in the city of Rhodes, on the northern tip of the island. It is a statue base, dated to the final quarter of the second century $\mathrm{BC}$ :

\begin{tabular}{|c|c|}
\hline 1 & 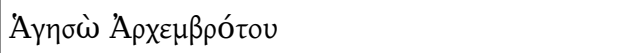 \\
\hline & 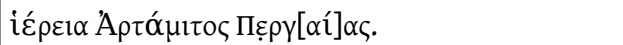 \\
\hline & 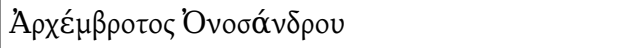 \\
\hline & 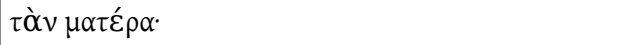 \\
\hline 5 & 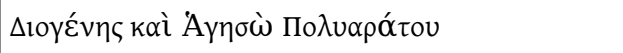 \\
\hline & $\tau \grave{\alpha} v \mu \alpha \tilde{\imath} \alpha v$. \\
\hline & 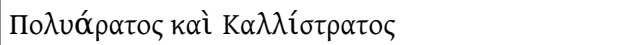 \\
\hline & 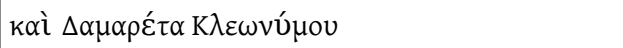 \\
\hline & $\tau \grave{\alpha} v \tau \tilde{\alpha} \varsigma \mu \alpha \tau \rho \grave{\rho} \varsigma \mu \alpha \tilde{\alpha} \alpha \nu$ \\
\hline 10 & [ө] \\
\hline & 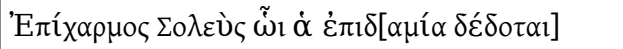 \\
\hline & 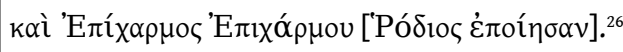 \\
\hline
\end{tabular}

18 Again, the text is striking within its wider epigraphic context: honorific statue bases for Rhodian priests are very common throughout the Hellenistic period, but are never found for priestesses. The only other exception comes from Lindos, from around $9 \mathrm{BC}$, and thereby substantially later in date than our previous examples. It is the right-hand section of a family monument. In it, a woman, whose name has been lost, is honoured; she was: 


\begin{tabular}{|c|c|}
\hline \multirow[t]{4}{*}{1} & {$[---------------]$} \\
\hline & 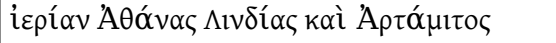 \\
\hline & 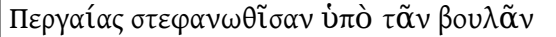 \\
\hline & 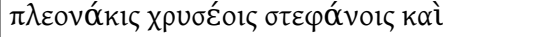 \\
\hline 5 & 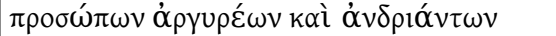 \\
\hline & 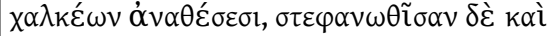 \\
\hline & 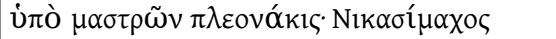 \\
\hline & 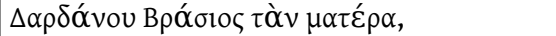 \\
\hline & 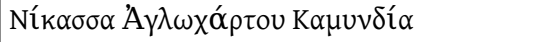 \\
\hline \multirow[t]{5}{*}{10} & 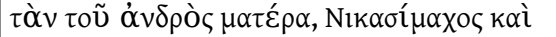 \\
\hline & 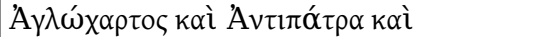 \\
\hline & 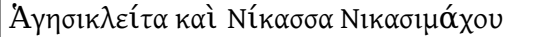 \\
\hline & 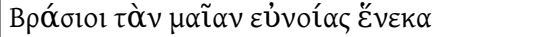 \\
\hline & 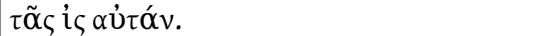 \\
\hline 15 & $\theta \varepsilon \circ \operatorname{lich}^{27}$ \\
\hline
\end{tabular}

19 On the surface, neither text bears any signs that it might be at all out of the ordinary. And yet they constitute the only two clear mentions of a priestess in Rhodian Hellenistic and early Imperial honorific epigraphy - another vast corpus, with many hundred examples of statue bases set up for male priests, still today crowding the Lindian acropolis. Both texts mention the priesthood of Artemis Pergaia, and both indicate the involvement of relatives in the monument. This is far more pronounced in the Lindian text, which also forms part of a bigger family monument, spanning three generations of a clan of notable Rhodians, whose members were honoured for a variety of qualities and deeds. It is also only the Lindian text which speaks of actual - and costly - honours granted to the unknown woman, including golden crowns and statues. Crucially, it mentions public honours, bestowed, apparently on several occasions, by civic bodies: the boule and the mastroi. Again, we are made aware of the different levels of the Rhodian state: the monument was set up on the Lindian acropolis, and the woman is honoured by the mastroi, a body of local councillors. However, the text also states that the priestess was granted high honours on a state level - by the Rhodian boule. This might suggest that the cult of Artemis Pergaia was a "state" cult and certainly attests to this woman's achievements and prominence within Rhodian society.

Since we find no male priests of Artemis Pergaia on Rhodes (nor anywhere else), we might justifiably assume that this was a cult - perhaps like that of Artemis es Phagas that required women to perform that role. Were it not for the ubiquity of male priests of the ancient and much more prominent cult of Artemis Kekoia on the island, this would not be a strange or surprising observation. about the important cult of Athena Lindia, despite still showing gaps, is far more 
substantial than for most Rhodian religious practice; perhaps most famous is the account provided by the remarkable "Lindian Chronicle" about the legendary visitors believed to have visited the sanctuary and bestowed votive gifts on the goddess. ${ }^{28}$ Other evidence, once again, concerns male priests, almost three hundred of whom are attested in the priestly catalogue alone. ${ }^{29}$ So what are we to make of this sudden reference to a priestess of Athena Lindia?

Before we seek to find an answer, a final, and relevant, inscription must be mentioned: this, too, is early Imperial in date, and also describes a Lindian woman as iereia Athanas Lindias, listing substantial honours paid to her:

\begin{tabular}{|c|c|}
\hline & 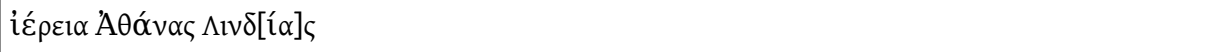 \\
\hline & 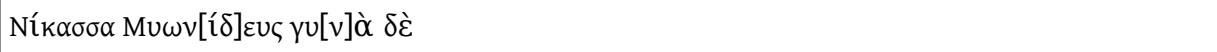 \\
\hline & 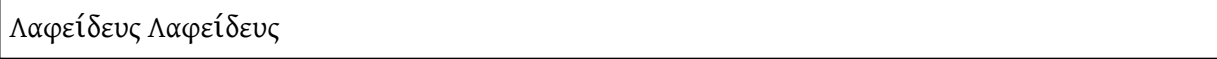 \\
\hline & 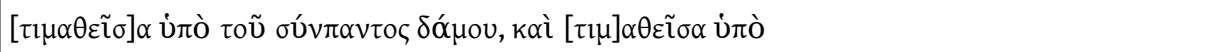 \\
\hline 5 & 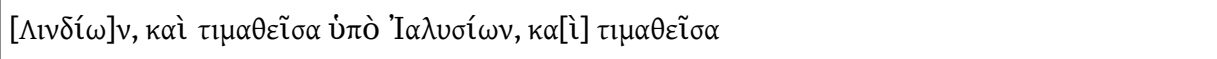 \\
\hline & 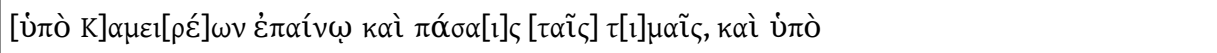 \\
\hline & 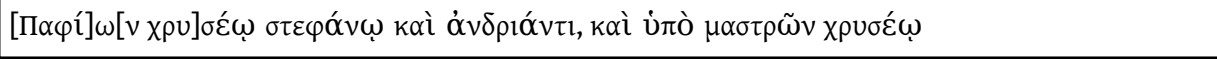 \\
\hline & 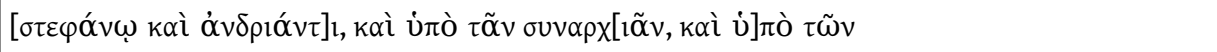 \\
\hline 10 & 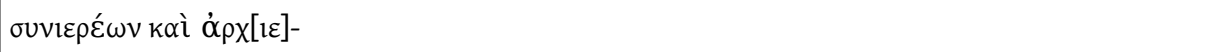 \\
\hline & 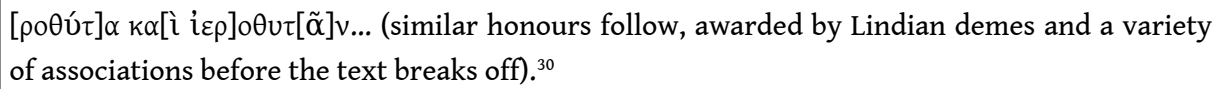 \\
\hline
\end{tabular}

The editor of this text as well as of the previous inscription, Christian Blinkenberg, noted that in both cases the women are related to the current (male) priest of Athena Lindia - in the first case she is his mother, in the second his wife. As a conclusion, he imagined it to be an honorary title, adopted by female relatives of priests in this period, but conveying no actual sacerdotal duties or responsibilities. ${ }^{31}$ His assessment is supported by the familial connections, by the exceptional nature of these two texts, as well as by the fact that Nikassa's stele lists honours paid to her husband, Lapheides, priest of Athena, beneath the text quoted. However, Blinkenberg does not consider possible changes in cult, nor does he take into consideration the Lindian epigraphic habit. It is certainly worth emphasising that Nikassa, like the unknown priestess discussed above, received impressive state-wide honours, conferred by the sympas damos as well as the three tribes of the Rhodian state. Her public prominence in the honorific landscape of the Lindian acropolis is further demonstrated by the existence of two statue bases bearing her name. ${ }^{32}$ To what extent this relates to her position as "priestess" is difficult to determine, and will be revisited below.

\section{Gods and Goddesses, Priests and Priestesses? Some Possibilities}

24 What has this brief exposition of the epigraphic sources revealed about Rhodian priestesses and the issues mentioned in the introduction? On a basic level, it has served 
to demonstrate how most civic cults were dominated by male priests, with only a very small number of priestesses attested - in the cults of Athena Polias (at Kameiros), potentially Athena Lindia, and certainly Artemis Pergaia and the deme-cult of Artemis es Phagas. It is only in the latter two that we find no evidence for male priests; in both Athena cults, the mentions of priestesses are problematic and vastly outnumbered by references to priests. Our evidence for priestesses appears even less substantial when we note the wide chronological spread: the four certain mentions of priestesshoods are scattered across three centuries. In addition, it is worth emphasising again the evidence for exclusively male priests tending to important civic cults of Artemis Kekoia, Aphrodite and Athena Polias (in Rhodes-town). ${ }^{33}$

Why is it that we find women so underrepresented in the priestly organisation of Hellenistic Rhodes? More specifically, why are they so curiously absent from the vast majority of cults of female deities, in which we might expect to find priestesses? I see two aspects to explore: first, I will consider regional and ritual elements of the main civic cults of female deities on Rhodes and ask whether there is something in the nature of these cults that might explain the gender imbalance. In the second section, I will investigate a different possibility, that it is the nature of our evidence, the particular epigraphic culture of Hellenistic Rhodes, that conceals priestesses from our view. The organisation of the Rhodian state, and the civic importance and opportunities provided by holding priesthoods at the tribal level has a significant bearing on this aspect. In addition, it will be important to consider the chronological spread, and whether it indicates a development in the epigraphic, or more specifically, honorific habit in the late Hellenistic or early Imperial period. This latter point reminds us that it is the representation of female religious personnel that we are by necessity focusing on, which, although informative on women's role in Rhodian society, need not entirely reflect reality.

Let us begin by testing our evidence against the "gender-rule", that is, the general observation that cults of goddesses tended to be served by priestesses, not priests. As noted in the introduction, there are numerous exceptions to this rule throughout the Greek world, particularly for cults of Athena, but also for other goddesses. Many of them come from poleis in the general area of Asia Minor and nearby islands. ${ }^{34}$

The regional angle might well be worth further exploration, but even within parallel cases, no city appears to exhibit a situation quite like Rhodes. ${ }^{35}$ In fact, scholars who discuss cases where the "gender-rule" did not apply, usually call on specific aspects of the cult or deity to explain the anomaly they are faced with: frequently these are cases where two divinities are worshipped as a pair, one male, one female; ${ }^{36}$ alternatively, "masculine" aspects of a goddess may be emphasised, such as the military character of some cults of Aphrodite. ${ }^{37}$ It might be argued that this principle could explain the existence of priests of Athena on Rhodes: worshipped on each acropolis (Ialysos, Kameiros, Lindos and Rhodes-town), she was linked on each of these sites to Zeus Polieus. But this explanation is inadequate on many levels: first, despite the joint worship, it was always Athena who was the primary deity, so much so that the priests in question were frequently referred to as just "priest of Athena"; secondly, where we can trace the earlier stages of the cult, it seems that Athena was also worshipped from earlier on, being conjoined with Zeus only in the late fourth or third century ${ }^{38}$ finally, the supremacy of Athena for Rhodians is attested in other ways and sources, from mythology to dedications. ${ }^{39}$ 
The gender of a divinity's main clientele might also play a role in the choice of a ritual specialist. ${ }^{40}$ In this context, it is worth mentioning the exclusion of women from a sacrifice to Athena Apotropaia in Lindos, recorded in an inscription from around $400 \mathrm{BC}$. Restrictions on women exist in similar contexts, but never in a cult of Athena. ${ }^{41}$ In this particular instance, it presumably reflects an unusual, cult-specific regulation of a relatively minor deity - a later addition to the text repeats the same restriction for Zeus Apotropaios, implying that this rule is connected with the epithet -, but should nonetheless be borne in mind. ${ }^{42}$ What (admittedly limited) evidence we have for the nature of the acropolis Athena cults in the different cities of Rhodes certainly does not exclude female worshippers or their concerns, quite the contrary. A brief look at the votive deposits of the temple of Athena at Lindos suggests a substantial female presence, with large numbers of fibulae and statuettes of women, although caution is needed in assuming a straightforward, traditional gender bias in these offerings. The substantially larger number of female than male figurines might, nonetheless, demonstrate the predominance of women in the day-to-day rituals and worship of this cult on the Lindian acropolis. Statuettes representing women carrying infants or accompanied by children reinforce this view, suggesting perhaps that Athena Lindia fulfilled a kourotrophic role within the community. ${ }^{43}$

For Kameiros and its local Athena cult the material evidence is even less helpful. Yet for this cult, we should reconsider the inscription cited above, listing sacrifices made to the goddess by various religious officials. The occasion that concerns us is the sacrifice by the priestess on the "dichomenia" of the month of Artamitios; that is, at the time of the full moon, in the month named after the goddess Artemis. The same event required a sacrifice of a lamb by the so-called "anthestrides", whose name literally means something like "flower-girls" and apparently denoted girls before marriage. ${ }^{44}$ Dillon, who uses Blinkenberg's reconstruction of the Kameiran text, believes this event to be a sacrifice to Artemis. While I believe that Athena Polias must be the recipient, ${ }^{45}$ Dillon's comments about the potential transitional element of girls' lives being at the heart of this ritual still rings true - or, at the very least, plausible. ${ }^{46}$ Whether or not the timing of the full moon was significant in this respect, ${ }^{47}$ a strong case can be made that our fragmentary sacrificial inscription informs us about a ritual celebrated by and relevant to girls or women on Rhodes, and associated with the cult of Athena Polias. If this is true, it might suggest that the sacerdotal role of the - otherwise unattested - priestess of this cult was limited primarily or solely to "feminine" rituals. Such a conclusion, however, must remain speculative, since our evidence for the ritual duties of the male priests of this cult is itself limited almost entirely to the text in question.

Particular cultic aspects may also explain the presence of female priests of Artemis Pergaia and Artemis es Phagas. For the latter cult we have so little evidence that it would be unwise to conjecture anything. We must limit ourselves to the general observation that it is a cult of Artemis, a goddess whose sphere often covered significant transitions in women's lives, and whose cult was usually attended by female priests in the Greek world. This also holds for the cult of Artemis Pergaia, but here we can also draw on further evidence. This goddess' epithet, hearkening back to her native Perge ${ }^{48}$ links these Rhodian cults to a wider cultic network: it certainly existed at Halikarnassos as well as at Naukratis, Oinoanda, Aspendos, Thera, Ambrakia and Arsinoites. ${ }^{49}$ of particular relevance is epigraphic and archaeological evidence for a temple of the deity at Loryma - a town in the Rhodian peraia. ${ }^{50}$ An early Hellenistic 
funerary inscription from Loryma informs us of a priestess of the goddess, with the unusual name of Europa ${ }^{51}$ In this case, it is possible that the presence of a female priest was an element that was deemed integral to this cult, wherever it travelled to (certainly no male priests are attested for this goddess anywhere).

On the one hand, we find a picture perhaps not so very different from what we might expect; the limited evidence we do have for priestesses seems to relate to particularly feminine rituals and cults. On the other hand, however, this does not explain the absence of priestesses from other Artemis cults - significantly of Artemis Kekoia - nor does it square with the "feminine" aspects of the worship of Athena explored above. The fact that male priests served all these cults, in addition to that of Aphrodite, cannot be explained purely by ritual or cultic aspects or peculiarities. The one mention of a priestess of Athena Polias remains particularly puzzling in this context - why do we not find her mentioned anywhere else in our source material? Might this have implications for the type of evidence we are working with, and its reliability?

One possible and plausible answer to these questions is that our picture is the result of the type of material that survives, and therefore is related to the epigraphic habit specific to Rhodes. This priestly epigraphy and the main types of documents we find were described above.

33 As we saw, both the priest lists and the joint dedications by synhiereis focus on the substantial number of annually revolving male priesthoods, and their relationship with each of the cities' eponyms. Holding one, or several, of these yearly religious offices was one way in which Rhodians could display their names in their civic and religious centres, both in catalogues and through votive offerings commemorating the end of their term in office. In view of these considerations, it perhaps comes as no surprise to find certain religious officials excluded from this body of priestly epigraphy: most notably, holders of life priesthoods and, apparently, female priesthoods (perhaps an overlapping category). Notwithstanding the dangers of arguing from silence, this recognition opens up the possibility that, despite the richness of our evidence, we are missing a substantial part of the picture of priestly personnel on Hellenistic Rhodes particularly that relating to ritual duties and more purely religious aspects. It is tempting to postulate, in consequence, that there might have been many more priestesses, from cults either known or unknown to us, barred from our evidence by the male-oriented epigraphic culture of the Rhodians.

34 A particular case in point concerns the cult of Demeter: when Donato Morelli compiled his work on the cults of Rhodes in the 1950s, he commented that, aside from some faint traces of a cultic presence (the month name Thesmophorios; theophoric associations named after the goddess; highly fragmentary sacrificial regulations $\mathbf{s}^{52}$ ), there was little to no evidence for civic worship of Demeter (and Kore). ${ }^{53}$ Crucially, no priests of the goddess survive in the epigraphic record of any of the Rhodian cities. And yet, since Morelli, further evidence has come to light, confirming the worship of Demeter in Rhodes-town: a sanctuary of the goddess has been located at the north-eastern boundary of the city, identifiable by votive offerings, typical of Demeter cults - e.g. hydriae, lamps, figures holding hydriae, pigs, or a basket, kourotrophoi, dancers, korai discovered there in vast numbers. ${ }^{54}$ The traces are sufficient to point to substantial civic worship in the city, implying that there would have been cult officials of some description. The marked disparity between the epigraphic and archaeological record in this instance might be highly revealing: was this, perhaps, a cult whose organisation 
and care was in the hands of priestesses (or women performing a similar role), whose names are however lost to us, due to their non-conformity to the prime categories of Rhodian priestly epigraphy? This consideration might also cause us to revisit with less scepticism a highly restored Lindian inscription dated to the late second century BC, reading, with Blinkenberg's supplements:

\begin{tabular}{|c|c|}
\hline & 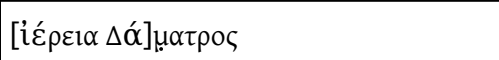 \\
\hline & {$[----] \alpha \Lambda \cup \sigma i ́ \omega v \circ \varsigma$} \\
\hline & 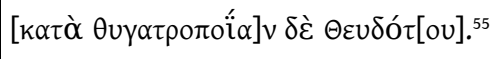 \\
\hline
\end{tabular}

Although one might question the precise wording and reconstruction, a reference to a priestess or other female religious official of Demeter no longer seems far-fetched, in light of the archaeological evidence. Chronologically it is clearly later than the references to priestesses in the sacrificial regulations, and if it is indeed an honorific text it appears to be the earliest of this type that mentions a priestess.

In many ways, this theory of "lost" priestesses is compelling; it recognises the potential bias of the source material, and provides an easy way out from our apparent conundrum, by positing that the reason we have so little evidence for priestesses on Rhodes is because we have lost the relevant sources, and the sources that do survive are interested in the annually changing priesthoods, held exclusively by men, and focusing on the civic and political significance of these offices. This is backed up by the ritual texts, limited though they are, which suggest no disparity between the responsibilities of male and female priests. Yet this does not suffice as an explanation. For it discounts the final, substantial, type of epigraphic documents that inform us about Rhodian priesthoods: honorific inscriptions. The majority of these refer to men who held either a priesthood or a secular civic office; but some also name women. Three of our examples above fall into that category: the inscriptions honouring Hageso, the unnamed priestess of Artemis Pergaia and Athena Lindia, and Nikassa - to which we may add the reconstructed attestation of the priestess of Demeter. It is difficult to explain the vast disproportion between priesthoods and priestesshoods mentioned in this category of inscription in the same way - particularly since we know of numerous inscriptions set up for women which do not mention any priesthoods. ${ }^{56}$ The silence in this area is more definite, and appears to confirm that, even if priestesses were not completely absent on Rhodes, they existed only in a limited number of cults and circumstances - and, perhaps more significantly, were almost never represented in this capacity in the public sphere.

\section{The Public Representation of Rhodian Women}

What do these observations about the relative absence of priestesses in the public religious structures of Rhodes tell us? Crucially, what do they tell us about the role of women and priesthoods in wider Rhodian society? As mentioned above, a common interpretation of women's religion, and priestesshoods in particular, is that it provided women with ways of gaining social cachet or prominence not otherwise available to them in the public sphere of the polis; in Kron's words, "A sacerdotal office enhanced enormously the social position of a woman." ${ }^{57}$ Must we then conclude that Rhodian 
women, since they were left out of religious organisation, suffered even greater marginalisation than was usually the case in Greek society? If so, why was this the case?

Let us initially reconsider the honorific inscriptions cited above, alongside some others, to establish what social prestige, if any, Rhodian women could gain from association with priesthoods - and in what time period.

The first-century BC statue base set up for Hageso, the priestess of Artemis Pergaia in Rhodes-town, mentions no specific honours, but does demonstrate an involvement by several generations of family members in the statue's dedication. ${ }^{58}$ Similar inscriptions from Lindos and Kameiros - of statuary dedications made on behalf of male priests by family members - demonstrate that this was a common custom among certain families in Hellenistic Rhodes. ${ }^{59}$ Such cases speak to the esteem in which priesthoods were held by elite families and their private efforts at monumentalising these achievements, demonstrating the offices' public prestige and social cachet. In addition, their dedication to the gods (theois) implies a public sanctuary setting for these "private" honours, just like other family monuments and statues set up on the Lindian acropolis. ${ }^{60}$ Similarly, even though no civic honours are attested for Hageso, her statue provided a visible presence for her in Rhodian society, as priestess of Artemis Pergaia.

The two Lindian inscriptions from the Imperial period that mention "priestesses" of Athena Lindia both have a more public character, and should be reconsidered in this context. The case of the woman (name unknown) who is commemorated as irpíav

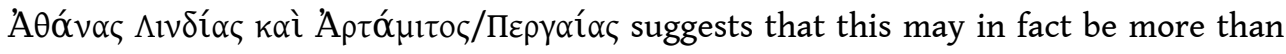
the mere honorary title that Blinkenberg suggests. ${ }^{61}$ The parallel construction of icpíav as applying to both cults rather implies that it had the same meaning for both. Since we certainly know of priestesses in the "normal" sense for Artemis Pergaia, this meaning should not be entirely discounted for the cult of Athena Lindia. In addition, the fact that the synhiereis are listed in the second case, among the groups honouring Nikassa should not be overlooked, nor that, in a fragmentary inscription also referring to her,

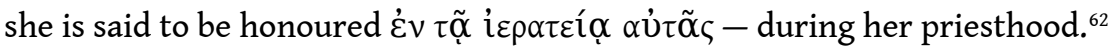

For both Lindian women we find a substantial list of impressive honours, from public as well as private groups. In the case of the unknown woman, her inscription forms part of a family exedra; all other members in this constellation received public honours, placing her squarely within the competitive honorific context of Lindian society. ${ }^{63}$ If these women had statues erected and were presented with crowns and other honours, it is certainly conceivable that they had involved themselves in some way in this highest Lindian cult, and the political capacity that clearly went along with it; if they shared their husband or son's title as priest, a great mark of distinction at Lindos, they may have had a connection to the duties performed. In the context of late Hellenistic and early Imperial honorific statuary, we may imagine an involvement in financial contributions or benefactions - an area in which women increasingly participated. ${ }^{64}$ The case of Nikassa is particularly revealing in this instance: as mentioned above, she receives honours from the Rhodian state, the sympas damos, inscribed on a stele that mirrors almost precisely that set up for her husband, Lapheides, priest of Athena. There is substantial overlap between the honours and honouring bodies, but they are not identical, suggesting that Nikassa is being treated at least in part independently from her husband. In addition to this inscription, there survive two statue bases of Nikassa on the Lindian acropolis, at least one of which lists further public honours: we learn that Nikassa is granted stephanephoria in all future festivals. ${ }^{65}$ Undeniably, then, 
Nikassa had a highly visible presence on the Lindian acropolis, with at least two statues, in addition to an honorific stele to her name. The evidence for her public honours demonstrates a substantial civic recognition and involvement, while the attestation of her stephanephoria implies both an ability to make substantial financial contributions, but also carries with it religious connotations. We might speculate that it was both her wealth and her family and marital connections that translated into religious and thus civic capital.

The Lindian priesthood of Athena, with which both of these women were associated, is worth exploring further in this context. In $11 \mathrm{BC}$, we find a monument that records, on one block, a fairly standard honorific inscription to Mnasias, priest of Athena Lindia, who is being honoured by his wife, his daughter, and eight other relatives, spanning three generations; on the other block, the dedication of an aparche to Athena Lindia by Boularista, the wife of Mnasias, is recorded. ${ }^{66}$ The combination of the two dedications, one emphasising the wider family's pride in Mnasias' priesthood, the other recording his wife's independent votive offering to the same deity, seems to demonstrate both a joint interest of husband and wife in this goddess' priesthood, and Boularista's own active engagement with the cult. This shared activity and also recognition is further demonstrated in a curious example of a dedication by Lindian synhiereis: a large base for two bronze statues is inscribed, on the left-hand side, with the name and title of the eponymous priest of Athena Lindia of $42 \mathrm{BC}$, Philippos, son of Philippos. On the right side, underneath a second statue, the same list of synhiereis appears, underneath Philippos' wife's name, Agauris. Both lists are followed by identical descriptions of the couple's crowning by the Lindian demos. Agauris is even praised with the same customary formula used of other eponymous priests in these texts. ${ }^{67}$ This parallel honour demonstrates a recognised inclusion of the eponym's wife in his business, presented through the highly visible medium of public statues and crownings. Whatever their precise involvement or responsibility in the cult may have been, it remains striking, nonetheless, that these women are not themselves priestesses possibly reflecting once again the non-ritual aspects of these eponymous priesthoods. The examples remain few and for the most part rather late, and even where we find these substantial honours recorded, the women remain visibly linked to their husbands (the "proper" priest).

Given the relatively late occurrence of these "priestesses" of Athena and their connection with their husbands, it is tempting to see this development as inspired by the trend in many cities of Asia Minor and the eastern Aegean for religious offices to be held jointly by married couples. According to van Bremen's careful study of this phenomenon, clear-cut cases are not attested before the first century AD. ${ }^{68}$ Conceivably, an awareness of such practices in nearby cities might explain the occurrence of the women calling themselves "priestess" of Athena Lindia in the Imperial period, although the evidence of Agauris and Boularista, just cited, points also to earlier involvement by wives in at least some aspects of their husbands' priesthoods. Perhaps the potential for such joint participation provided the impetus for (briefly) attempting to import a more formalised institution for these husband-and-wife pairs, modelled on the development in other poleis. The limited occurrence of these joint priesthoods on Rhodes suggests, however, that this adaptation was not very successful; it only seems to have been applied to the priesthood of Athena Lindia, and even here 
the cases are few. It is possible that this reflects the rigid structure of Rhodian priesthoods, and the lack of space within their civic capacities for women to partake in.

On the one hand, these examples demonstrate that, however limited in number, the connection between public honours and priestly offices or responsibilities could exist for Rhodian women, just as for other Greek women - at least by the late Hellenistic and early Imperial period. ${ }^{69}$ We see them crowned by the demos, boule, or other public bodies, and receiving statues. Sometimes this seems to be due to their familial connections with a priest, but nonetheless expressed in individual terms and with individual honours. On the other hand, the extremely limited number of these cases remains significant - as does their late date. The theory posited above that further female cult personnel, such as priestesses of Demeter, might be concealed from our view due to the epigraphic habit of Hellenistic Rhodes, can thus also be seen to be reflected in honorific statuary. Even if in reality there were numerous priestesses of Demeter, or of Athena Polias, the fact remains that, for the most part, they were not represented in the prominent civic and religious locations of Rhodes - to underline this point, we need look only to the numerous statue bases honouring priestesses of both Demeter and Athena in nearby Hellenistic centres, such as Priene, Erythrai, or Pergamon. ${ }^{70}$ The exceptions that I discussed above show that there was some development in Rhodes, with a small number of women receiving state-level honours and honorific monuments set up in public spaces in the later first century $B C$ in connection with priesthoods. Even so, the evidence remains extremely limited.

Within the wider context of Rhodian honorific epigraphy, statues of Hellenistic Rhodian women are primarily found within the context of family dedications, in which they are honoured by relatives in their role as wife, mother, sister, or grandmother. Around 20 such statue bases survive, either as part of a greater monument, or else honouring the woman individually. As Eule points out, even within this category of family monuments, women appear less than men, representing only around a third of statues set up in this context. ${ }^{71}$ The familial focus is typical of Hellenistic Rhodes, which, despite its democratic government, was marked by seemingly more "aristocratic" epigraphic display. ${ }^{72}$ Yet the women commemorated in this way are, for the most part, not praised for their religious duties. Besides the rarity of priestesshoods, we should note the complete absence of positions like kanephoroi appearing in the epigraphy; positions through which, as the Chorus in Aristophanes' Lysistrata so succinctly explains, citizen girls and adolescents participated in and contributed to the well-being of their polis, and which, in Athens, could serve as a valuable status symbol for competitive elite families. ${ }^{73}$ Above, I discussed the attestation of anthestrides on Rhodes, likely a ritual position held by adolescent girls, whose duties included sacrifice to Athena Polias in Kameiros. The votive deposit from Athena's sanctuary at Lindos includes statuettes of what appear to be kanephoroi, as well as hydrophoroi, plausibly suggesting their existence and association with this cult. ${ }^{74}$ But once again, we find no match in the honorific epigraphy, no women or girls being honoured or commemorated for dutifully fulfilling their role as one of the anthestrides or kanephoroi of Athena on Rhodes.

Aside from statuary, Rhodian women are found depicted in funerary art, where they appear in a prominent position, while their names are recorded in a number of public and private subscriptions from the Hellenistic period, and we even find female names on amphora stamps. These methods of representation do not contribute much to our 
investigation of women's roles in the religious organisation of Rhodes, but they do indicate that such extreme marginalisation is not found in other categories of art and epigraphy. ${ }^{75}$

What this demonstrates in view of the subject of this paper is that, while there are some signs of female activity in Rhodian public life, these are far outweighed by representations of them in private life - more particularly in family life. Towards the end of our period there appears to be a change, with greater public honours granted to wives of Rhodians who held prominent positions in the religious organisation. The apparent correlation between the relative lack of public honours and the limited representation in religious roles also casts further light on the highly political flavour of priesthoods and eponymous offices in Rhodian society. Men recorded and were honoured for their accumulation of such "religious" positions in a variety of contexts, demonstrating the significance of these structures for competition and status. Although Rhodian women could gain recognition through holding religious office, or else through a close association with such a position, they were largely excluded from this system of eponymic and other priesthoods, focused as much of it was on the civic careers of men.

\section{Some Conclusions}

The close analysis of the priestesshoods of one rich case of relatively narrow scope has thus thrown up a number of significant observations and problems with recent scholarship: first, it has demonstrated that, at least in Hellenistic Rhodes, priestesses were certainly not as well-represented as priests, and in fact appear to have been excluded from sacerdotal duties relating to the most important cults of the island state. In the few cases where priestesses are referred to in our Rhodian epigraphic sources, I have asked whether they conform to the general assumption in scholarship that female priests played a particularly significant role in communication with female deities. Although the (rare) examples of priestesses of Artemis and of Athena do fit into this picture, there are also numerous cases of men being charged with the cultic responsibility of goddesses in the supposedly "feminine" sphere, which substantially problematizes this assumption. The lack of evidence for ritual responsibilities might, however, be skewing our picture, and pushes us to question the terminology of "priest" or hiereus in all our cases. Given the civic nature of most of our evidence for Rhodian priests, it is not at all clear that we should necessarily be thinking in terms of ritual or religious roles and responsibilities.

A brief look at other geographical regions, particularly those nearby, suggests that such exceptions were more common than is often supposed - although this impression needs to be supported by future studies into regional religion.

In any case, this paper is no comparative study, interesting as such an approach would be. Rather it seeks to determine whether, aside from particular cultic aspects, there might be other local features that explain the absence of women from the vast majority of priestly inscriptions. The Rhodian epigraphic habit and its interest in commemorating specific religious officials in long lists as well as joint dedications, both types of document emphasising the annual rotation of these positions, goes some way to explain the high representation of men in our evidence, and reflects the particular organisation of Rhodian polis religion. On the other hand, priestesses' near-total 
absence from honorific monuments indicates that this is, again, only a partial explanation.

51 The problematic nature of our evidence notwithstanding, the results of my study can be viewed on two separate levels: first, that of the evidence: given the extremely low number of priestesses that are attested from Hellenistic Rhodes, despite the relatively rich epigraphic corpus, and the substantial evidence for male priests in charge of the cults of female deities, we can, with some certainty, state that men outnumbered women significantly in this sphere. Some priestesses certainly existed, as we have seen, and there may have been some more, removed from our sight by the type of source material that survives to us. In the limited sample of sacrificial calendar extracts, we find female cult personnel, and no apparent distinction between their ritual responsibilities and those fulfilled by male priests. But this latter observation is precisely what renders my conclusion on the second level much more certain: the level of representation. For even if there were truly numerous "lost" priestesses, we find no sign of them in the public sphere, dominated as it is by men recording their achievements in accumulating these politically valuable religious offices. However, the evidence analysed above hints at a change: the inscriptions that record substantial public honours for women either themselves described as "priestess", or else related to a priest, date to the late Hellenistic and early Imperial period. Nothing of this kind survives from the earlier part of our period, when similar honours appear to be reserved for men, and the only mentions of priestesses refer to their ritual responsibilities. It is tempting to attribute this to a change in women's role in society, possibly due to access to and involvement in financial matters and euergetism, and we may wonder to what extent Rhodes is following the trend set by other centres in the eastern Aegean.

This civic identity of male priests on Rhodes, suggested by the types of epigraphic documents that survive in such abundance, is further strengthened by the fact that actual evidence for priestly duties is extremely limited. Aside from the small number of sacrificial regulations - two of which in fact mention priestesses as we saw above the epigraphic sources record priests only in honorific contexts, joint dedications, and priest lists. Although they surely did also carry out sacrifices and other ritual duties, it is worth emphasising that these Rhodian priests are more commonly found in contexts that do not distinguish them greatly from secular magistrates. In consequence, it is worth raising the question of terminology again, and asking how "priestly" these hiereis really were. Taken alongside the evidence discussed above of the highly structured and hierarchical system of priesthoods, we might begin to see a fuller picture of this maleoriented cultic organisation of Rhodes, and its competitive nature within both public and private honorific landscapes on the island - although it still does not allow us to explain why and when it developed in this way.

Finally, we should consider the implications for women in Hellenistic Rhodian society: does their relative lack of religious authority translate into a more limited public role in general? The fact that the only substantial Hellenistic public honours found accorded to a woman are those for Agauris, wife of the priest of Athena Lindia, indicates the potential prominence offered by these high priesthoods - here as elsewhere in the Greek world. By the early Imperial period, we find Nikassa receiving extensive honours and several statues, indicating, perhaps, an increase in public representation of women within the religious sphere. We should remember that, in the late second century BC, 
Hageso, priestess of Artemis, receives no such recognition, while Agauris is merely the wife of the current priest. As I indicated, there are signs of somewhat greater prominence of women in the private and familial spheres, but even here we do not find indications of cultic roles performed. In itself, the correlation between few public honours and limited representation of priestesses need not underline the equation of women's religion to their role in society, but it does seem to fit into this general picture.

54 Is Rhodes, then, an exception in the lack of importance it bestows on women active within the religious sphere? Certainly, it is different from Athens, and, consequently, appears to form a significant deviation from what is commonly perceived to be the norm, namely that women played a prominent role in civic religion, particularly in cults of female deities. In addition, it problematizes our understanding of the term "priesthood" by highlighting a society in which civic and political functions are advertised to a much greater degree than cultic ones. An effect of this appears to be the near-complete absence of women from priestly representation. This study thus aims to nuance the general link drawn between women's cultic roles and their public visibility, serving as a reminder of the individuality of Greek religion in the polis.

\section{Abbreviations}

In addition to standard abbreviations, for which see $O C D$ ed. 4 , note:

\begin{tabular}{|l|l|}
\hline CGRN & $\begin{array}{l}\text { J.-M. CARBON, S. PEELS and V. PIRENNE-DELFORGE, A Collection of Greek Ritual Norms (CGRN), } \\
\text { Liège, 2016- (http://cgrn.ulg.ac.be, consulted in September 2017). }\end{array}$ \\
\hline I.Lindos & $\begin{array}{l}\text { C. BLINKENBERG, Lindos. Fouilles et recherches, 1902-14, II. Inscriptions, 2 vols., Berlin/ } \\
\text { Copenhagen, 1941. }\end{array}$ \\
\hline Tit.Cam. & $\begin{array}{l}\text { M. SEGRE and G. PUGLIESE CARRATELLI, “Tituli Camirenses”, ASAA 27-29 (1949-1951), p. 141- } \\
318 .\end{array}$ \\
\hline
\end{tabular}

\section{BIBLIOGRAPHY}

ACKERMANN, D., "Les prêtrises mixtes : genres, religion et société," in M. HORSTER and A. KLÖCKNER (eds.), Cities and Priests: Cult Personnel in Asia Minor and the Aegean Islands from the Hellenistic to the Imperial Period, Berlin/Boston, 2013, p. 7-39.

BADOUD, N., Le temps de Rhodes : une chronologie des inscriptions de la cité fondée sur l'étude de ses institutions, Munich, 2015.

BEAN, G.E., Lycian Turkey: An Archaeological Guide, London, 1978.

BENEDIKTSSON, J., Chronologie de deux listes de prètres kamiréens, Copenhagen, 1940. 
BLINKENBERG, Chr., Lindos. Fouilles et recherches 1902-1914, I. Les petits objets, Berlin/ Copenhagen, 1931.

-, "Règlements de sacrifices rhodiens," in Dragma, Martino P. Nilsson, a.d. IV id. iul. anno MCMXXXIX dedicatum, Lund, 1939, p. 96-113.

-, Lindos. Fouilles et recherches 1902-1914, II. Inscriptions, Berlin/Copenhagen, 1941.

BLÜMEL, W. (ed.), Die Inschriften der rhodischen Peraia, Bonn, 1991 (IK 38).

BRESSON, A., Recueil des inscriptions de la Péreé rhodienne (Pérée intégrée), Besançon/Paris, 1991 (Centre de recherches d'histoire ancienne, 105).

BUDIN, S.L., "Aphrodite Enoplion," in A.C. SMITH and S. PICKUP (eds.), Brill's Companion to Aphrodite, Leiden/Boston, 2010, p. 79-112.

BURKERT, W., Greek Religion: Archaic and classical, Oxford, 1985.

COLE, S.G., Landscapes, Gender, and Ritual Space: The Ancient Greek Experience, Berkeley/London, 2004.

CONNELly, J.B., Portrait of a Priestess: Women and Ritual in Ancient Greece, Princeton, 2007.

DETIENNE, M., "The violence of wellborn ladies: Women in the Thesmophoria," in M. DETIENNE and JP VERNANT (eds.), The Cuisine of Sacrifice among the Greeks, Chicago/London, 1989, p. 129-147.

DIGNAS, B., "Rhodian priests after the synoecism," AncSoc 33 (2003), p. 35-51.

DILLON, M.P.J., Girls and Women in Classical Greek Religion, London, 2002.

-, “ 'Chrysis the hiereia having placed a lighted torch near the garlands then fell asleep' (Thucydides IV.133.2). Priestesses serving the gods and goddesses in Classical Greece," in S.L. BUDIN and J.M. TURFA (eds.), Women in Antiquity: Real Women across the Ancient World, London/ New York, 2016, p. 683-702.

EULE, J.C., Hellenistische Bürgerinnen aus Kleinasien: weibliche Gewandstatuen in ihrem antiken Kontext, Istanbul, 2001.

FABRICIUS, J., "Gelagerte Frauen: Überlegungen zu einer ikonographischen Besonderheit rhodischer Totenmahlreliefs und zur sozialen Stellung der Frau im hellenistischen Rhodos," in E. KYPRAIOU and D. ZAPHEIROPOULOU (eds.), Rodos 2,400 chronia: Hē polē tēs Rodou apo tēn hidrysē tēs mechri tēn katalēpsē apo tous Tourkous (1523): Diethnes epistēmoniko synedrio, Rodos, 24-29 oktovriou 1993: Praktika, Athens, 1999, p. 207-214.

FRASER, P.M., "The tribal-cycles of eponymous priests at Lindos and Kamiros," Eranos 51 (1953), p. 23-47.

GABRIELSEN, V., The Naval Aristocracy of Hellenistic Rhodes, Aarhus, 1997.

-, "The synoikized polis of Rhodes," in P. FLENSTED-JENSEN, T.H. NIELSEN and L. RUBINSTEIN (eds.), Polis and politics: Studies in Ancient Greek History, Presented to Mogens Herman Hansen on his sixtieth birthday, August 20, 2000, Copenhagen, 2000, p. 177-205.

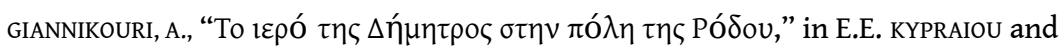
D. ZAPHEIROPOULOU (eds.), Rodos 2,400 chronia: Hē polè tēs Rodou apo tēn hidrysē tēs mechri tèn katalēpsēe apo tous Tourkous (1523): Diethnes epistēmoniko synedrio, Rodos, 24-29 oktovriou 1993: Praktika, Athens, 1999, p. 63-72.

GOFF, B., Citizen Bacchae: Women's Ritual Practice in Ancient Greece, Berkeley, 2004. 
GRAF, F., Nordionische Kulte: Religionsgeschichtliche und epigraphische Untersuchungen zu den Kulten von Chios, Erythrai, Klazomenai und Phokaia, Rome, 1985.

HABICHT, C., “Ein kaiserzeitliches Familiendenkmal aus Lindos,” ZPE 84 (1990), p. 113-120.

-, "Notes on the priests of Athena Lindia," Studi Hellenistici 15 (2005), p. 71-78.

HELD, W., “Loryma in Karien: Vorbericht über die Kampagnen 1995 und 1998," MDAI(I) 49 (1999), p. 159-196.

-, "Forschungen in Loryma 1998," in 17. Araştırma Sonuçları Toplantısı, Ankara 1999, Band II, Ankara, 2000, p. 295-306.

-, "Neue und revidierte Inschriften aus Loryma und der karischen Chersones," EA 36 (2003), p. $55-86$.

-, "Die Heiligtümer und Kulte von Loryma," in R. vAN BREMEN and J.-M. CARBON (eds.), Hellenistic Karia, Talence, 2010, p. 355-377.

HENRICHS, A., "What is a Greek priest?," in B. DIGNAS and K. TRAMPEDACH (eds.), Practitioners of the Divine, 2008, p. 1-14.

HIGBIE, C., The Lindian Chronicle and the Greek Creation of Their Past, Oxford, 2003.

HOLDERMAN, E.S., A Study of the Greek Priestess, Chicago, 1913.

HORSTER, M., "Lysimache and the Others: some notes on the position of women in Athenian religion," in G. REGER et al. (eds.), Studies in Greek Epigraphy and History in Honor of Stephen V. Tracy, Pessac, 2010, p. 177-192.

KONTORINI, V., Anekdotes epigraphes Rodou 2 = Inscriptions inédites de Rhodes, Athens, 1989.

KOWALZIG, B., Singing for the Gods: Performances of Myth and Ritual in Archaic and Classical Greece, Oxford, 2007.

KRON, U., "Priesthoods, dedications and euergetism; what part did religion play in the political and social status of Greek women?," in P. HELLSTRÖM and B. ALROTH (eds.), Religion and Power in the Ancient Greek World: Proceedings of the Uppsala Symposium 1993, 1996, p. 139-182.

LORAUX, N., "What is a Goddess?," in G. DUBY and M. PERROT (eds.), A History of Women in the West Vol. I, Cambridge (MA)/London, 1994, p. 11-44.

LUPU, E., Greek Sacred Law: A Collection of New Documents, Leiden, 2004 (RGRW, 152).

MA, J., Statues and Cities: Honorific Portraits and Civic Identity in the Hellenistic World, Oxford, 2013. MARTELLI, M., "La stipe votiva dell' Athenaion di Jalysos. Un primo bilancio," in S. DIETZ and I. PAPACHRISTODOUlou (eds.), Archaeology in the Dodecanese, Copenhagen, 1988, p. 104-115.

-, "La stipe votiva dell'Athanaion di Ialiso," in M. LIVADIOTTI and G. Rocco (eds.), La presenza italiana nel Dodecaneso tra il 1912 e il 1948: la ricerca archeologica, laconservazione, la scelte progettuali, Catania, 1996, p. 46-50.

MATHYS, M., Architekturstiftungen und Ehrenstatuen: Untersuchungen zur visuellen Repräsentation der Oberschicht im späthellenistischen und kaiserzeitlichen Pergamon, Darmstadt, 2014.

MIGEOTTE, L., “Une souscription de femmes à Rhodes,” BCH 117:1 (1993), p. 349-358.

MORELLI, D., I culti in rodi, Pisa, 1959 (SCO, 8).

MORRICONE, L., “I sacerdoti di Halios,” ASSA 11-13 (1952), p. 351-380. 
MYLONOPOULOS, J., “Commemorating Pious Service: Images in Honour of Male and Female Priestly Officers in Asia Minor and the Eastern Aegean in Hellenistic and Roman Times," in M. HORSTER and A. KLÖCKNER (eds.), Cities and Priests: Cult Personnel in Asia Minor and the Aegean Islands from the Hellenistic to the Imperial Period, Berlin/Boston, 2013, p. 121-153.

OSBORNE, R., "Women and sacrifice in classical Greece," CQ 43:2 (1993), p. 392-405.

PARKER, R., "Subjection, synoecism and religious life," in P. FUNKE and N. LURAGHI (eds.), The Politics of Ethnicity and the Crisis of the Peloponnesian League, Cambridge, MA/London, 2009, p. 183-214.

PAUL, S., Cultes et sanctuaires de l'île de Cos, Liège, 2013 (Kernos, suppl. 28).

-, "Roles of civic priests in Hellenistic Cos," in M. HORSTER and A. KLÖCKNER (eds.), Cities and Priests: Cult Personnel in Asia Minor and the Aegean Islands from the Hellenistic to the Imperial Period, Berlin/ Boston, 2013, p. 247-278.

PIRENNE-DELFORGE, V., L'Aphrodite grecque, Liège, 2013 (Kernos, suppl. 4).

PIRONTI, G., Entre ciel et guerre. Figures d'Aphrodite en Grèce ancienne, Liège, 2007 (Kernos, suppl. 18).

-, "Des dieux et des déesses : le genre en question dans la representation du divin en Grèce ancienne," in S. BOEHRINGER and V. SEBILLOTTE CUCHET (eds.), Des femmes en action : l'individu et la fonction en Grèce antique, Paris, 2013, p. 155-167.

PRICE, S., Religions of the Ancient Greeks, Cambridge, 1999.

-, "Greece," in S.I. JoHnston (ed.), Religions of the Ancient World, Cambridge, MA/London, 2004, p. 302-305.

RICE, E.E., "Prosopographika Rhodiaka,” ABSA 81 (1986), p. 209-250.

SEGRE, M., "Rituali rodii di sacrifici," PP 6 (1951), p. 139-153.

SOKOLOWSKI, F., Lois sacrées de l'Asie mineure, Paris, 1955.

SOURVINOU-INWOOD, C., "Male and female, public and private, ancient and modern," in E. REEDER (ed.), Pandora: Women in Classical Greece, Baltimore, 1995, p. 111-120.

TRÜMPY, C., "Feste zur Vollmondszeit: Die religiösen Feiern Attikas im Monatslauf und der vorgeschichtliche attische Kultkalender," ZPE 121 (1998), p. 109-115.

VAN BREMEN, R., The Limits of Participation: Women and Civic Life in the Greek East in the Hellenistic and Roman Periods, Amsterdam, 1996.

VELIGIANNI-TERZI, Chr., Damiurgen: Zur Entwicklung einer Magistratur, 1977, Diss. Ruprecht-KarlsUniversität Heidelberg.

WIKANDER, C., "Religion, political power and gender - the building of a cult-image," in

P. HELLSTRÖM and B. ALROTH (eds.), Religion and Power in the Ancient Greek World, Uppsala, 1996, p. $182-188$.

ZERVOUDAKI, E., "Vorläufiger Bericht über die Terrakotten aus dem Demeter Heiligtum der Stadt Rhodos," in S. DIETZ and I. PAPACHRISTODOULOU (eds.), Archaeology in the Dodecanese, Copenhagen, 1988, p. 129-137. 


\section{NOTES}

1. PRICE (2004), p.303. Cf. also sourvinou-InWood (1995), p.111, who describes women as "complementary and equal to men" in the public religious sphere.

2. CONNELLY (2007), p. 2.

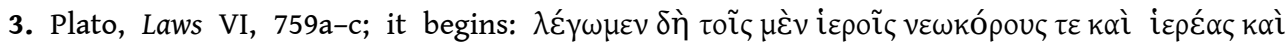

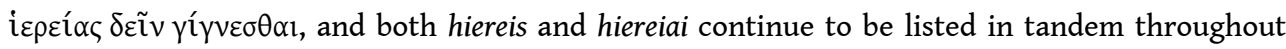
the passage.

4. KRON (1996), p. 140 with n. 6; PRICE (1999), p. 68; COLE (2004), p. 126.

5. CONNELLY (2007); DILLON (2002); GOFF (2004).

6. The dangers of over-emphasising the role of women and particularly priestesses specifically in Athenian religion was commented on by HORSTER (2010). In justifying her extremely narrow approach to a paper on religion, political power, and gender, WIKANDER also warned: "Given the scarcity of sources available, scholars tend to use more or less everything at hand, sometimes without proper attention to time-spans, either between the facts recounted or between the sources that recount them; furthermore, localities need to be taken into account" (WIKANDER [1996], p. 182).

7. Addressed, of course, in LORAUX (1994), albeit with no discussion of the sacerdotal connection; more recently on this topic, PIRONTI (2013); COLE (2004), p. 122-128, already offers a more sophisticated and nuanced account of the "gender-rule".

8. DILLON (2016), p. 699: "Communities recognised that it was women who had to deal with women gods and that men could not empathise with fertility or love deities". On the complicated relationship between gender and ritual see COLE (2004), p. 92-95; she also stresses the importance of the gender of the worshipping group of different cults.

9. Gonnoi: Helly, Gonnoi II, no. 151; Herakleia under Latmos: SEG 40 956; Kos: IG XII 4, 2:998; LSCG 151 A 1.56; LSCG 156 A 1. 21; Thera: IG XII 3, 495; Tegea: Paus. 8.47.5. HoldERMAN (1913) outdated but still (to my knowledge) the only attempt at accumulating this evidence. The existence of searchable online databases of names and epigraphic corpora of course greatly aids and supplements this kind of research nowadays.

10. By the Hellenistic period it certainly also included the mainland territory referred to as the "incorporated peraia", as well as a number of nearby islands; however, our evidence for these areas and their precise relationship to the other elements of the Rhodian state and religious organisation is not always clear. For this reason, my focus in this article is on the island of Rhodes.

11. On the synoikism: GABRIELSEN (2000); on the effects of synoikism on religious organisation: PARKER (2009).

12. MORRICONE (1952), p. 351-380, at p. 360-363. So far, lists have been found for the following priests: at Lindos, priests of Athena Lindia [and Zeus Polieus], Poseidon Hippios, Artemis Andromeda and Zeus Patroos; at Kameiros, damiourgoi [priests of Hestia and Zeus Teleios], priests of Athena Polias, archieristai, priests of Apollo; at Ialysos, priests of Apollo Erethimios; at Rhodes-town, prophatai, and priests of Helios and Asklepios. BADOUD (2015), chs. 2, 4, 5, 6, 8; TRI 1, $2,5,6,8,9,10,12,13$.

13. Sacrificial duty: Tit.Cam. $152=$ LSS $97=\operatorname{SEGRE~(1951),~n.~2;~now~also~CGRN~110.~The~title~}$

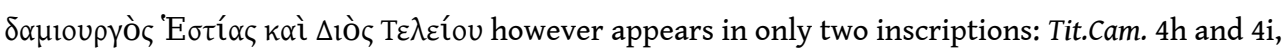
of which the latter, at least, dates to the Roman period. See MoRelu (1959), p. 135. This combination also appears in some Kameiran dedications: Tit.Cam.62, 64, 67, 78. Nonetheless, VELIGIANNI-TERZI [1977], p. 120-133 prefers to see the damiourgoi as civic officers with sacred characteristics and duties. 
14. The term "synhiereis" in fact appears only in Lindian inscriptions, and largely dates to the first century BC; however, it is a useful word to describe the groups of annual priests whose names and offices were inscribed together in both Kameiros and Lindos from the third century onwards.

15. There are slight differences in the dates of the evidence from Kameiros and Lindos and also variation in the length/number of names included. Only one clear example referring to priests of cults of the Rhodian state survives, but conforming to the same document-type: I.Lindos 134.

16. Note especially the long list of priests of Athena Lindia at Lindos (I.Lindos 1), of Athena Polias at Kameiros (Tit.Cam.5) and mentions of male priests of Athena Polias and Aphrodite in two third-century dedications by Rhodian priests: I.Lindos 134 and Tit.Cam. 24. To what extent these deities were particularly "feminine" will be revisited below.

17. BLINKENBERG (1941), p. 89-106; BENEDIKTSSON (1940); MORRICONE (1952); FRASER (1953); HABICHT (2005); BADOUD (2015).

18. DIGNAS (2003) on the idea that these priesthoods formed a sort of "religious cursus honorum", through which Rhodians could ascend to the highest office of the state, the priesthood of Helios.

19. I.Lindos 680 (with slightly different reading) = LSS $92=$ CGRN 154. BADOUD (2015), p. 219 dates it to c. $230-170 \mathrm{BC}$, based on paleography.

20. BLINKENBERG (1939); SEGRE (1951); LUPU (2004), p. 69-70.

21. Most are published in LSS 92-104.

22. Tit.Cam. $148=$ LSS $96=$ CGRN 109 .

23. BLINKENBERG (1939) believed that this text was a fragment from a public sacrificial calendar,

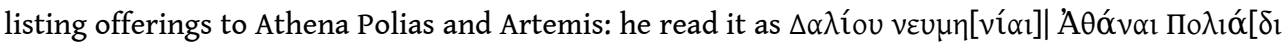

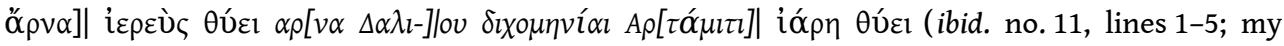
italics); Segre, however, basing his argument on a larger number of parallels and a revised reading of the text, denied that this document was breaking the general pattern of referring to only one deity, and suggested the following corrections, accepted since, in all subsequent

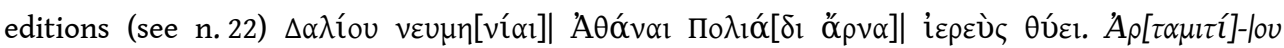

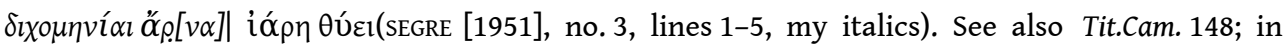
general, SEGRE (1951), p. 142-147.

24. For a possible other sacrifice on this date, see the highly fragmentary Tit.Cam. $149=$ LSS 99 .

25. See e.g. Tit.Cam. 5, 15, 17, 24, 27-31, 35-39a.

26. IG XII 1, 66.

27. I.Lindos 384e. See HABICHT (1990) on this monument; date from BADOUD (2015), p. 235.

28. I.Lindos 2; HIGBIE (2003). It is worth noting, in this context, that the "Lindian Chronicle" also mentions a male priest of Athena, who is given an important role in one of the goddess' epiphanies: D95-113.

29. I.Lindos 1; BADOUD (2015), p. 37-74; TRI 12.

30. I.Lindos 392a. Dated to AD 10 by BADOUD (2015), p. 235.

31. BLINKENBERG (1941), p. 105-106.

32. I.Lindos 394; 395.

33. A highly fragmentary statue base from Rhodes-town might also refer to an assistant priestess: SER 27, which begins [--- $\dot{v}] \varphi \imath \varepsilon \rho \varepsilon \alpha v \mathrm{~K} \alpha \lambda \lambda ı[--]$. For attestations of such a position on Kos see IG XII 4, 326, 1. 23-24 and 68 with Paul (2013a), p. 119-121.

34. See e.g. Pirenne-Delforge's comments on religious personnel of Aphrodite: PIRENNE-DELFORGE (2013), p. 398-400. Based on the limited evidence, she cautiously postulates that regional trends might account for the difference in gender.

35. Thus, for instance Kos, where we find male priests of Athena attested, also provides several instances of priestesses. Note in particular the case of Kallistrate who, in the second century BC, was priestess of Asklepios, Hygieia, Epione, Apollo Delios, Leto and Eumenes: IG XII 4, 978; 
CONNELly (2007), p. 55; MYlonopoulos (2013), p. 129 (on the priestess' statue). We also find priestesses of Demeter making dedications to the goddess: ConNelly (2007), p. 140, and purity regulations prescribed for them: PAUL (2013a), p. 77-79. On the distinction between male and female priesthoods in Koan diagraphai, see PAUL (2013b), p. 253-254, who, however, also lists two exceptions, in which women held male priesthoods

36. HOLDERMAN (1913), p. 7-10.

37. Male priest of Aphrodite Strateia attested for Mylasa in I.Mylasa 203; cf. GRAF (1985), p. 177; on this epithet of the goddess see soкоLоWsкi (1955), p.155, who argues against a military connotation, suggesting instead that this epithet is a rendering of the Carian Labraundos; also BUDIN (2010), p. 83-85, 103-104 and PIRONTI (2007), p. 268-273. The latter provides a strong and nuanced argument for more military and "masculine" conceptions of Aphrodite in general. Reservations are voiced by BUDIN (2010), but Pironti's work nevertheless highlights significant associations of the goddess with the masculine sphere, reminding us of the problems of regarding Greek deities as straightforwardly gendered.

38. On the development of the Athena cult at Lindos to include Zeus: BLINKENBERG (1941), p. 102103 and BADOUD (2015), p. 44-46.

39. In general: KOWALZIG (2007), p. 224-266.

40. COLE (2004), p. 127-128, especially for cults of Dionysos.

41. $L S S 88=$ CGRN 62 a 1.5 , also stipulated for the sacrifice later added to the same inscription for Zeus Apotropaios; for an identically phrased restriction on women see the extract prescribing a sacrifice for Zeus Amalos, also from Lindos, dated to c. 400 BC: CGRN 63. Cf. CGRN 27 for the exclusion of women as not 'themis' from a Thasian sacrifice to Herakles, with concise discussion of this phenomenon in the commentary.

42. There has been much scholarly debate on Greek women's participation in sacrifice; DETIENNE (1989) argues most strongly for a general prohibition, with only few exceptions, in line with women's limited political roles in the Greek polis; his extreme position was countered by OSBORNE (1993), who argues that sacrificial regulations excluding women, including the Lindian one referred to here, relate to marginal cults, rather than particularly political ones, and suggests instead that such "prohibitions on women are cult-specific" (p. 403). Comparable epigraphic examples, however, all relate to male deities.

43. BLINKENBERG (1931), p. 34-37; female figurines: nos. 2101-2310. These are distinct from the statuettes depicting the goddess Athena herself: nos. 2332-2336. On Athena as a kourotrophos see KOWALZIG (2007), p. 234-235. Women carrying drinking vessels, BLINKENBERG (1941), nos. 2998-3002; hydrophoroi: nos. 3003-3012; women carrying baskets with offerings: nos. 3014-3016 and fruit baskets: nos. 3023-3029; women holding a tympanon: nos. 3037-3042; women carrying torches: nos. 3018-3022.

44. Hesych. s.v. "anthesteriades" (presumably a variant of the same term); DILLON (2002), p. 61-62.

45. See n. 23 above.

46. DILLON (2002), p. 61-62.

47. A common time of the month for major Athenian festivals; for the possibility that these would have been at least partly nocturnal see TRÜMPY (1998), p. 112-113.

48. E.g. BEAN (1978), p. 26-28.

49. HELD (2010), p. 368; References in BLÜMEL (1991), p. 14; BRESSON (1991), p. 160-161; MORELLI (1959), p. 30-31.

50. A temple of Artemis Pergaia has been identified at Loryma: HELD (1999), p. 167; HELD (2000), p. 300; HELD (2010), p. 368-70. Its dedicatory inscription has been published in HELD (2003), no. 12.

51. IK Rhod.Peraia 21: interestingly this Europa is said to be Egyptian - an element we do not find attested for the cult on the island - while her husband bears the ethnic Aspendios. Perhaps this provides us with a further indication of the network this cult was tied into? 
52. Two from Lindos whose restoration to include Demeter's name is highly questionable: I.Lindos 181 and 182; sceptically on these already: SEGRE (1959), p. 152. The text from Kameiros, on the other hand, clearly refers to a sacrifice to $\Delta \alpha \mu \alpha$ ó $\varepsilon \varepsilon \rho \sigma ı v$, that is, to Demeter and Kore: Tit.Cam. 156a. 53. MORELLI (1959), p. 119-121.

54. ZERVOUDAKI (1988), p. 129. GIANNIKOURI (1999) has suggested that the finds might match a cult of Demeter Thesmophoros - with outdoor space rather than a temple, and remains of lamps, perhaps indicating nocturnal activity.

55. I.Lindos 261: fragment of statue base; with photo.

56. E.g. IG XII 1, 108, dated to the first century BC is a statue base for Philotera, set up and dedicated by six members of her family; cf. in general EULE (2001), p. 107-112.

57. KRON (1996), p. 140.

58. IG XII 1, 66; cf. MYLONOPOULOS (2013), p. 129.

59. E.g. I.Lindos 83, 96, 100, 158; Tit.Cam. 84, 91, 97. MA (2013), p. 202-212 on the emphasis on familial networks and relations between individuals in such Hellenistic inscriptions, all while making a mark on public space.

60. MA (2013), p. 169-175 on private monuments commemorating public office (including priesthoods); p. 213-214 on the public dimension of private honorific statuary, with particular reference to Rhodian "CV" inscriptions.

61. BLINKENBERG (1941), p. 105-106. Cf. VAN BREMEN (1996), p. 134.

62. I.Lindos $394,1.10$. Although her name is lost, it can be restored confidently due to the survival of her husband's name in the second line.

63. See MA (2013), p. 193-194 on the interaction and competition between public and private honorific monuments; also p. 214-225.

64. See in general VAN BREMEN (1996); for Rhodian women: MIGEOTTE (1993). More below.

65. I.Lindos 394 and 395; 394 might include honours granted by the mastroi, but this is only cautiously restored.

66. I.Lindos 382a and b; see RICE (1986), p. 217-220 for the most likely reconstruction of the relationships of the various family members to Mnasias (the honorand).

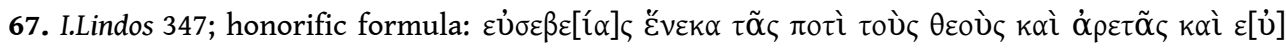

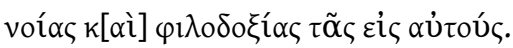

68. VAN BREMEN (1996), p. 114-117.

69. Statuary for female priests: EULE (2001), esp. p. 124-127; CONNELLY (2007), esp. p. 117-163.

70. EULE (2001), p. 71, 93-102, 103-107; for Pergamon see: MATHYs (2014), p. 25-26 (Hellenistic statues of priestesses of Athena) and p. 34-35 (honorific statues in the sanctuary of Demeter); also p. 37. She notes the role of sanctuaries in providing honorific spaces for elite women in late Hellenistic and early Imperial Pergamon.

71. EULE (2001), 112.

72. GABRIELSEN (1997), p. 15-17 on Rhodian aristocracy; MA (2013), p. 202-212 on familial monuments and display.

73. Ar. Lys. 638-47; DILLON (2002), p. 37-42 on kanephoroi and their status in Athens.

74. See above n. 43.

75. Fabricius, in her study of Rhodian Totenmahl reliefs, points out that the iconographic representation of women in these monuments presents them in an unusually prominent position, reclining on couches in the same manner as men. In addition, some bear symbols of education, such as a scroll: FABRICIUS (1999). For the monuments in question see PFUHL - MÖBIUS nos. 1547, 1844-1888, 2025-2027, 2039. For an epidosis consisting solely of female donors from Rhodes see MIGEOTTE (1993): in total 21 contributions of citizen and foreign women survive, with sums ranging from 100 drachmas to just 5 . Migeotte believes this to be a private, rather than civic enterprise, possibly connected with an association. All women are accompanied by a kyrios. 
Women were also honoured as euergetis in associations: IG XII 1, 114 and 385; KONTORINI (1989), no. 10 for women in associations. Appearance on amphora stamps: VAN BREMEN (1996), p. 266-267.

\section{ABSTRACTS}

This article questions the commonly assumed prevalence of women in Greek Hellenistic priesthoods, often considered to put them on equal footing with men in this sphere, through the particular case study of Rhodes, a state whose religious organisation appears entirely dominated by male priests. It suggests that it is time to revise some of the general assumptions about women and Greek religion by placing greater emphasis on regional variations. Consequently, it argues that local organisation and the epigraphic habit likely played a role, and examines in detail the evidence that does survive for Rhodian priestesses. Do these appear in particularly "feminine" cultic contexts? Can we find any evidence for a "gender-rule" of priesthoods? Finally, this article considers the limited public representation of women in Hellenistic Rhodian society, and what light this casts on our understanding of priesthoods.

L'article interroge ce qui apparaît comme une évidence, à savoir la prévalence des femmes dans le cadre des prêtrises grecques de la période hellénistique, souvent considérées comme étant mises sur le même pied que les hommes, alors qu'à Rhodes, l'organisation religieuse apparaît comme entièrement dominée par les prêtres. Il est temps de réviser certains points de vue sur les femmes dans le cadre de la religion grecque en mettant davantage l'accent sur les variations régionales. L'organisation locale et la pratique épigraphique jouent l'une et l'autre un rôle, quand on examine en détail la documentation conservée sur les prêtresses rhodiennes. Les contextes où elles apparaissent sont-ils particulièrement "féminins » ? Peut-on identifier une "règle genrée » pour la dévolution des prêtrises? Enfin, l'article envisage la faible représentation publique des femmes dans la société hellénistique rhodienne et s'interroge sur ce que cela nous dit des prêtrises.

\section{AUTHOR}

\section{JULIANE ZACHHUBER}

Oriel College, Oxford

Juliane.zachhuber@oriel.ox.ac.uk 